\title{
ДУХОВНО-ІНТЕЛЕКТУАЛЬНЕ ВИХОВАННЯ ШКОЛЯРІВ ХАРКІВСЬКОГО ЛЮЕЮ № 89 ХАРКІВСЬКОЇ МІСЬКОЇ РАДИ ХАРКІВСЬКОЇ ОБЛАСТІ
}

\author{
Г. О. Жозе да Коста \\ аспірантка кафедри загальної педагогіки і педагогіки вищої школи ХНПУ імені Г. С. Сковороди
}

Сучасне реформування української школи стверджує необхідність якісного оновлення змісту освіти, забезпечення безперервного процесу становлення та розвитку гармонійної творчої особистості учня. Школа бере на себе місію створення нового освітнього середовища, де панує атмосфера педагогічної творчості вчителів — однодумців, учнів і батьків. У Концепції «Нової Української школи» зазначено: «Потужну державу і_конкурентну економіку забезпечить згуртована спільнота творчих людей, відповідальних громадян, активних і підприємливих. Саме таких повинна готувати середня школа України» [6].

Нове освітнє середовище передбачає й новий зміст освіти, нові технології навчання і виховання, розвиток інтелектуальних здібностей дітей, щоб вивести кожного школяра на виховання культури творчого мислення. Сьогодні школа має готувати не лише носія знань, а й творчу особистість, яка здатна використовувати здобуті знання для конкурентоспроможної діяльності у будь-якій сфері суспільного життя, тобто формувати компетентну особистість. Розвиток у школяра самостійності, здатності до самоорганізації, саморозвитку, самовиховання, самоосвіти - це одне з першочергових завдань сучасної освіти.

Сучасний зміст виховання в Україні складає науково обгрунтована система загальнокультурних і національних цінностей та відповідна сукупність соціально значущих якостей особистості, що характеризують іiі ставлення до суспільства і держави, інших людей, самої себе, праці, природи, мистецтва. Система цінностей і якостей особистості розвивається і виявляється через ії власні ставлення. Цей процес передбачає поєднання інтересів особистості - вільного саморозвитку і збереження своєї індивідуальності; суспільства — саморозвиток особистості має здійснюватися на моральній основі; держави, нації - діти мають зростати, стати національно свідомими громадянами, патріотами, здатними забезпечити країні гідне місце в цивілізованому світі.

Метою духовно-інтелектуального виховання школярів Харківського ліцею № 89 є формування духовного світогляду та інтелектуального розвитку на основі творчої самореалізації школярів. Зміст духовно-інтелектуального виховання має спрямовуватись на формування системи духовно-інтелектуальних цінностей у становленні морального світу особистості з можливостями їх збагачення кожним учнем. Система морального виховання спрямована на формування цілісної моральної особистості, яка включає такі гуманістичні риси, як доброта, чуйність, милосердя, увага, толерантність, совість, чесність, справедливість, людська гідність, повага і любов до людей, правдивість і скромність, сміливість і мужність.

Великі можливості у вирішенні цього завдання забезпечує застосування методу навчальних проектів. На думку I. Єрмакова, система освіти має стати гнучкою, спрямованою на розвиток проектного мислення, здатності ефективно вирішувати проблеми й виконувати життєві й соціальні ролі [10]. Як зауважує дослідник, сучасному суспільству потрібен не виконавець, а творець. Він має бути спроможний самостійно моделювати, створювати проекти, що відповідатимуть вимогам часу. Він здатний повноцінно жити й активно діяти в новому світі, а також постійно самовдосконалюватись, адекватно реагувати на зміни, особливо в періоди технологічних та цивілізаційних проривів. Цим зумовлено введення проектної діяльності в освітній контекст навчальних закладів. Зрештою, уміти створювати, реалізувати чи брати участь у проектах — вагома життєва компетентність особистості, основи якої можливо оптимально сформувати й розвинути в умовах навчання особистості в закладі загальної середньої освіти.

У Харківському ліцеї № 89 активізована робота з питань виховання громадської свідомості учнів, шкільного самоврядування, формування патріотизму, громадянських і конституційних обов'язків, поваги до державних символів України, національної ідеї, виховання економічної, естетичної, правової культури учнів, яка органічно вписується у зміст і методику навчальної і позаурочної роботи, в організацію життєдіяльності школярів за допомогою проектної діяльності.

У ліцеї було визначено напрями освітнього процесу, в яких можна створювати та реалізовувати проекти:

- навчальний процес (уроки, спецкурси, факультативи тощо);

- виховний процес (класні години, позакласна діяльність);

- учнівське самоврядування;

- гурткова діяльність (проектні майстерні);

- робота з батьками.

Уроки (факультативи) є основною формою організації навчання та виховання, що створюють сприятливі передумови для взаємонавчання, колективної діяльності та змагання. У навчальному процесі створюються переважно навчальні проекти. Навчальний проект з точки зору учня - це можливість максимального роз- 
криття власного творчого потенціалу. Навчальний проект з точки зору вчителя — це інтеграційний дидактичний засіб розвитку, навчання і виховання, що дозволяє виробляти й розвивати специфічні вміння та навички проектування в учнів.

Учнівське самоврядування сприяє виробленню в учнів важливого вміння - співпрацювати, що передбачає активну участь у життєвих процесах. Учні виконують активну роль як діячі, планувальники, а не лише як споживачі кінцевих результатів чи продуктів цих процесів.

Виховний процес (класні години, позакласна діяльність) — це заняття, які допомагають у вихованні людини, здатної до самовдосконалення. Проекти, створені в класному колективі, надають школярам різноманітну практику самоствердження у позитивній діяльності.

Проектні майстерні - це напрям гурткової діяльності, де займаються розробкою та створенням проектів у сфері дизайну, декоративно-прикладного мистецтва, технічного моделювання тощо. На заняттях проектних майстерень на основі наявного досвіду учні мають можливість створювати унікальні творчі матеріальні продукти.

Цікавою роботою щодо створення проектів є творча співпраця з батьками. Один із ключових компонентів концепції Нової української школи $є$ педагогіка партнерства — педагогіка, що грунтується на партнерстві між учнем, учителем і батьками. В основі педагогіки партнерства - спілкування, взаємодія та співпраця між учителем, учнем і батьками [7]. На батьках лежить певна частина відповідальності щодо того, якою людиною стане дитина в професійному, творчому, життєвому планах. Створення проектів вимагає від батьків та учнів таких умінь, як:

- пошук потрібної інформації;

- монтаж за допомогою комп’ютерної техніки;

- фотографування, оброблення та сканування зображень;

- пошук і підбір необхідної інформації в Інтернеті;

- оброблення на комп'ютері отриманої інформації;

- підготовка слайд-презентації.

Створення проектів у вищеназваних напрямах освітнього процесу передбачається адміністрацією ліцею як комплекс ціннісних напрямків. Це дає змогу долучити до проектної діяльності кожного учня з наданням можливості реалізації різних позицій членів групи (від виконавця до організатора).

Головним завданням духовно-інтелектуального виховання дітей в Харківському ліцеї № $89 є$ виховання і розвиток творчої, соціально-адаптованої особистості, професіонала-патріота України шляхом науково-методичного забезпечення демократичного розвитку освітнього процесу. Реалізація цього завдання ведеться у різних напрямках.

Працюючи за напрямком «Ціннісне ставлення особистості до суспільства і держави» в учнів виховується почуття поваги до своєї Батьківщини, любові до рідної природи тісно пов'язане з громадянським вихованням, основна мета якого полягає у формуванні в людини моральних ідеалів суспільства й почуття громадянського обов'язку, тобто вихованні самосвідомості й відповідальності за свою країну, готовності захищати свою Батьківщину, відстоювати принципи моралі, почуття національної гордості, відповідальності за збереження й примноження як національних, так і загальнолюдських цінностей, потреби в праці на благо суспільства. Для реалізації цих завдань учні приймали участь у проектах: «Дитячий малюнок пораненому бійцю», «Від теплої руки дитини захиснику моєї Країни», проект з виготовлення іграшки-оберіга для воїнів АТО; проект екранних робіт про мир щодо відзначення 73-ї річниці перемоги над нацизмом у Другій світовій війні.

Завданням напрямку «Ціннісне ставлення до сім’ї, родини, людей» $є$ формування моральної особистості (доброти, взаєморозуміння, милосердя, толерантності, культури спілкування), різнобічних духовних потреб та інтересів; виховання шанобливого ставлення до родини, поваги до народних традицій і звичаїв, національних цінностей українського народу відбувалось через реалізацію пропаганди позитивного іміджу сім ї та їі соціальної підтримки, формування культури сімейних стосунків, підвищення відповідальності батьків за виховання дітей, проводилися різноманітні зустрічі, бесіди щодо популяризації сімейного способу життя, формування національних сімейних цінностей з питань здорового способу життя та збереження репродуктивного здоров’я. У цьому напрямку учні Харківського ліцею № 89 упродовж навчального року приймали участь у міському конкурсі проектів «Харків очима небайдужих дітей» (проект «Майданчик для росту особистості»), флешмобі «Усмішка дитини» (виготовлення стрічки з фотографіями з посмішками учнів ліцею), святі-привітанні «Міжнародний день людини похилого віку», круглому столі «Моральний ідеал та його місце в житті людини», експрес-грі «Цінності моєї родини».

Завдання напрямку«Ціннісне ставлення до природи, до праці» — формування почуття єдності з природою, свідомого ставлення та любові до неї, виховання господаря. Найбільш цікавими проектами цього напрямку 
були: «Жити в злагоді з природою», «Шляхи зменшення екологічних ризиків у харчуванні».Ціннісне ставлення до природи розвивалось в учнів ліцею у процесі екологічного виховання, метою якого було формування в учнів усвідомлення функцій природи в житті людини та ії цінності, особистої причетності до збереження природних багатств, відповідальності за них; здатності гармонійно співіснувати з природою, поводитися компетентно, екологічно, безпечно; бажання брати активну участь у практичних природоохоронних заходах, здійснювати природоохоронну діяльність з власної ініціативи.

Упродовж навчального року для учнів Харківського ліцею № 89 були проведені екскурсії: до Харківського планетарію, до оранжереї Ботанічного саду, до Фельдман Екопарку. Учні активно брали участь в благодійних акціях «Чиста Україна - Чиста Земля», «Допоможемо Харківському зоопарку».

Учні ліцею залучалися до участі в екологічних десантах під час проведення акцій з очищення та благоустрою територій району, міста, брали активну участь у заходах в межах двомісячника «Зелена весна».

Формування в учнів різнобічних потреб самореалізації творчого потенціалу в різних сферах діяльності й спілкуванні, розвиток дитячих обдарувань через систему позаурочних форм роботи та ефективну взаємодію сім'ї та ліцею є основним завданням напрямку «Ціннісне ставлення до культури і мистецтва». Найбільш значущими проектами цього напрямку стали проекти до «Дня ліцею», «Дня Святого Миколая», «Дня святого Валентина», «Дня вишиванки»; новорічний конкурс-проект «Найкраща ялинка», пізнавальний проект «Моя улюблена країна світу».

3 метою залучення учнів до культурних цінностей українського народу протягом навчального року було організовано відвідування учнями театрів, музеїв, виставок, а також ряд різноманітних екскурсій та культпоходів, таких як: відвідування вистав у Харківському національному академічному театрі опери та балету імені М. Лисенка, Харківському державному академічному театрі ляльок імені В. А. Афанасьєва, театрі «Мадригал», відвідування Центрального парку культури та відпочинку ім. М. Горького, Харківського дельфінарію «Немо», Харківського планетарію, Харківського художнього музею, державного музею природи ХНУ ім. В. Н. Каразіна, роледрому в ТРЦ «Французький бульвар» та ковзанки у ТРЦ «Караван», відвідування виставки в галереї АВЕК, екскурсії до хлібозаводу «Кулиничі» та «Фельдман Екопарк», екскурсія містом «Харків - історичний».

Основними завданнями превентивного та правового виховання $€$ формування ціннісних ставлень у першу чергу до себе, сім'ї, родини, і як наслідок - до людей, суспільства, держави (наприклад усвідомлення того, що збереження особистісного здоров'я сприяє збереженню здоров'я нації, суспільства в цілому). Виконанню цих завдань сприяла реалізація напряму «Ціннісне ставлення до себе», в рамках якої упродовж навчального року було проведено: проект «Здоровій спосіб життя в традиціях українського народу»; правовий проект «Учнівська молодь і правопорушення»; проект за участю батьків «Чи може суспільство викорінити злочинність?»; проект «Екологічна культура сучасної людини».

За ініціативи організації учнівського самоврядування «САМ-89» учні ліцею брали участь у проектах: «Поважай мудрість», «100 днів позитивності», «Подаруй любов», «Компліменти», «Захист Вітчизни - свята справа», «Голос учнівської молоді», «Як подолати конфлікт?», «Пізнай себе».

Необхідно зазначити, що у процесі створення та реалізації кожного проекту учні опановували як сучасні, так і традиційні засоби проектної діяльності. Невід'ємною частиною інформаційного проекту є презентація, тому цей проект вимагав використання електронних засобів (комп'ютер, флеш-накопичувач, комп'ютерні програми Microsoft Office PowerPoint, Microsoft Office Publisher, Adobe Photoshop, сканер та відповідне програмне забезпечення Fine Reader).

У процесі створення практико-орієнтованого, творчого чи соціального проектів застосовують традиційні засоби навчання, а саме: паперові, магнітні. Мультимедійний проект вимагає освоєння мультимедійних технологій, тому основними засобами таких проектів виступають як традиційні, так і сучасні (комп'ютерні програми Macromedia flash, 3ds Max, PowerPoint).

Школа XXI століття зумовлює необхідність докорінного переосмислення освітньої парадигми, актуалізації змісту, технологій становлення особистості учня як суб'єкта і проектувальника життя, створення проектножиттєвого простору, спрямованого на розвиток і саморозвиток компетентної, конкурентоспроможної особистості, яка вміє творчо розв'язувати проблеми, прагне змінити на краще своє життя й життя своєї країни. Школа має захистити й підтримати дитину, виробити в неї життєздатність, озброїти механізмами і технологіями розробки життєвих стратегій та проектів. Місія школи спрямована на оволодіння кожною молодою людиною ключовими компетенціями, як важливим результатом якості освітнього процесу.

Навчання і виховання лише тоді мають реальну силу, коли вони грунтуються на вірі в дитину. Кожна дитина приходить до школи зі своїми інтересами, поглядами, проблемами, індивідуальними здібностями. I тільки від учителя та педагогічного колективу залежить, чи зможуть вони максимально розкрити потенційні 
можливості дитини, стимулювати їі до особистісно-розвивальної творчості. А в основу своєї роботи вчитель має покласти любов і повагу до дитини, опору на ії сили, внутрішній потенціал.

Педагогічний колектив має спрямувати свої зусилля на створення якісного освітнього середовища для навчання і виховання дітей, використання сучасних педагогічних, інформаційних технологій з урахуванням індивідуальних здібностей дитини, оволодіння новітніми технологіями навчання і виховання на основі здійснення моніторингу своєї діяльності, запровадження ефективного педагогічного досвіду, залучення школярів до активної громадської роботи на основі їх здібностей і потреб у самовираженні, залучення до співпраці батьків, працівників ВНЗ.

Інноваційні технології навчання і виховання дають можливість реалізовувати завдання виявлення, навчання і підтримки учнівської молоді.

Як результат, має бути створена система роботи, що забезпечує формування творчої особистості на основі використання інноваційних форм інтелектуально-пізнавальної діяльності, при цьому значно підвищується компетентність педагогів, зростає рівень якості навчання школярів, їхня громадська активність. Збільшується кількість учнів, що беруть участь у творчих конкурсах, науково-дослідницькій роботі.

Здобутки й успіхи педагогічного та учнівського колективу у духовно-інтелектуальному вихованні можуть бути тільки завдяки злагодженої, цілеспрямованої, осмисленої і систематичної взаємодії всіх складових освітнього середовища. Поєднання нових, прогресивних шляхів розвитку школи та модернізації управління нею, інноваційних технологій навчання й виховання з традиційними, перевіреними часом прийомами і методами організації освітнього процесу в Харківському ліцеї № 89 дають можливість створити умови для духовноінтелектуального виховання у контексті творчої самореалізації кожної особистості.

\section{Література}

1. Взаємодія учня і вчителя у площині проектної діяльності : матеріали роботи творчої групи педагогів Волинської області // Проектна діяльність у школі / упорядн. М. Голубенко. К. : Шкільний світ. С. 38-51.

2. Гончаренко С. У. Український педагогічний словник. К. : Либідь, 1997. 376 с.

3. Довбенко Т. Метод проектів в історії шкільництва // Шлях освіти. 2005. № 2. С. 47-51.

4. Срмаков І. Компетентнісний потенціал проектної діяльності. Проектна діяльність у школі / упорядн. Голубенко. К. : Шкільний світ, 2006. С. 5-18.

5. Мартинець Л.А. Проектна діяльність у навчально-виховному процесі загальноосвітнього навчального закладу // Освіта та розвиток обдарованої особистості. 2015. № 3 (34). C. 10-13. URL: http://nbuv.gov.ua/UJRN/Otros_2015_3_4.

6. Мірошник С. I. Теоретичні основи навчальної проектної діяльності учнів // Народна освіта. 2014. № 2 (23). URL: https://www.narodnaosvita.kiev.ua/?page_id=2383

7. Нова Українська школа. Концептуальні засади реформування середньої школи / упоряд. Л. Гриневич, О. Елькін, С. Калашнікова та ін. МOH України, 2016. 40 c. URL: http://mon.gov.ua/202016/12/05/konczepcziya.pdf

8. Нова українська школа: порадник для вчителя : навчально-методичний посібник / за заг. ред. Н. М. Бібік. К., 2018. 160 c. URL: https://www.pedrada.com.ua/article/2556-noviy-poradnik-dlya-vchitelya-nush

9. Освітні технології : навч.-метод. посіб. / Пехота О. М., Кіктенко А. З., Любарська О. М. та ін.; за заг. ред. О. М. Пєхоти. К. : АСК, 2002. 255 с.

10. Педагогічне проектування / авт.-упорядн. А. Цимбалару. К. : Шкільний світ, 2009. 128 с.

11. Проектна діяльність у ліцеї: компетентнісний потенціал, теорія і практика : наук.-метод. посібн. / за ред. С. М. Шевцової, І. Г. Єрмакова, О. В. Батечко, В. О. Жадька. К. : Департамент, 2008. 520 с.

12. Професійна освіта : словник : навчальний посібник / уклад. С. У. Гончаренко та ін.; за ред. Н. Г. Ничкало. К. : Вища школа, 2000. $380 \mathrm{c}$. 